\title{
Overlay Device
}

National Cancer Institute

\section{Source}

National Cancer Institute. Overlay Device. NCI Thesaurus. Code C50093.

A device designed to be applied over an object, typically for protection or identification. 